\title{
Political Communication Activities of Partai Keadilan Sejahtera (PKS) in the Openness of Ideology
}

\author{
Erfina Nurussa'adah*, Suwandi Sumartias, Soeganda Priyatna \\ Communication Science \\ University of AMIKOM \\ Yogyakarta, Indonesia \\ *erfina@amikom.ac.id
}

\begin{abstract}
For the sake of power, political parties will compete to open themselves to be able to accommodate all the bases of voters. This condition makes party ideology no longer a major element in internal party decision making, in addition ideology is no longer a benchmark in making policies. It becomes an interesting phenomenon when cadre parties or doctrinaire parties are increasingly open to secular or nationalist ideological parties, it leads the pragmatic party, PKS, became one of the Islamic parties that can be considered since its emergence because it managed to become a middle party and able to compete and even ahead of other Islamic parties. This study is intended to understand political communication activities in ideology openness involving Regional Leadership Council (DPW) of PKS of West Java. Political communication activities were observed through political communication activities of Regional Leadership Council of PKS of West Java through regional deliberations, regional work meetings, and regional coordination meetings. The approach used was qualitative with the study of communication ethnography. The data were obtained by observation, interview and document studies on 5 internal interviewees and 4 external interviewees. The result of this study showed that political communication activities in the openness of ideology of Regional Leadership Council (DPW) of PKS of West Java brought up aspects of communicative situations, communication events, communicative acts, political communication components, relationships between communication components in communicative events forming political communication patterns. Political communication activities in the openness of ideology of DPW of PKS of West Java is part of political strategy of PKS to form a more inclusive party image (open), moderate, tolerance, plural, to eliminate the stereotype of Ihwanul Muslimin or Wahhabism, and to achieve political goal that are to get support, and wider constituents.
\end{abstract}

Keywords-communication; DPW of PKS of West Java; ideology openness.

\section{INTRODUCTION}

Politics is the interaction and activity between groups of people with others to achieve common goals. The goal in politics can be achieved through cooperation. Cooperation to achieve common goals in politics was formulated by Lasswell with whom to obtain what, when, and how (who, gets, what, when, how). Who does the activity, when and how to achieve it [1]. Politics involves talking, it can be said that political activity is talking [2].

Political communication as a whole can be understood by connecting communication with the dimensions of politics and its aspects and problems. Number of points of view in political communication makes it difficult to define political communication. If we understand communication as a "messaging process", but if it is associated with political communication then it can be said to be "the process of delivering political messages". Hikmat in his book of political communication explains that political communication not only revolves around the delivery of political messages, but also discusses how communication can take place in a political system or system of government that includes how the system can be maintained and continues from generation to generation [3].

The presence of Islamic parties in Indonesia is a long history that became a necessity because the Islamic group helped build the Republic long before independence. But as a political party, Islamic parties are not independent of where they come from. Each Islamic party has its support base. Islamic party in Indonesia has a tendency toward three mainstream typologies namely the traditionalist party, the modernist party, and the Islamist party [4]. The traditionalist group is represented by the NU party whose social base is Nahdhatul 'Ulama. Then the modernist party is represented by Masyumi and Parmusi whose social base is represented by Muhammadiyah and other modernist mass organizations. Both have dominated the power of Islamic parties in Indonesia until the collapse of the New Order. The birth of the reform was accompanied by the birth of a new Islamist political force, Partai Keadilan Sejahtera (PKS).

$P K S$ Party was originally imaged as an exclusive party by carrying Tarbiyah Movement. Tarbiyah movement is a movement with the concept of Tarbiyah Islamiyah is the preparation of pious human beings in order to create a balance in the potential, purpose, speech, and action with the aim of creating conditions conducive for humans to live straight, both with the pleasure and reward of Allah SWT [5]. Another condition that makes PKS exclusive is its Qibla to the Middle 
East by making the Muslim Brotherhood's movement in Egypt as a model and inspiration movement.

The openness of ideology of political parties will affect the political communication strategy of the party for both the ruling party and the election. This condition also occurs in $P K S$. The decision to open up to all parties will affect the political communication of a political party, both internal and external. Political communication refers to any exchange of symbols or messages that to a significant extent have been shaped by or have consequences for the political system [2]. Thus it can be said that political communication is one of the process of communicating symbols or symbols of communication containing the political messages of a person or group to others in order to open the insight or way of thinking, and influence the attitude and behavior of the audience which became a political target [6].

The communication's point of view can be seen through the political communication activities behind the openness of ideology itself. This study is expected to give a description of ideology openness and provide information to the community about what is happening around them. The situations can be seen through the activities of political communication conducted by the $P K S$. The result of this study is expected to contribute in identifying and exploring political communication in ideology openness of $D P W$ of $P K S$

\section{RESEARCH METHOD}

The approach used in this study is a qualitative approach since this study tried to understand the political communication of $D P W$ of $P K S$ of West Java in its ideological openness. As stated by Creswell that [7]:

"...qualitative research is an inquiry process of understanding based on distinct methodological traditions of inquiry that explore a social or human problem. The researcher builds a complex, holistic picture, analyzes words, reports detailed views of informants, and conducts the study in a natural setting."

To find out the ethnography of political communication of the openness of $P K S$ 's ideology, the first stage was by identifying recurrent events and listing the components that build the communication and the last stage was by making the connection between the components known as the communication patterning [8].

- The first stage, the author identified any communication events that occur repeatedly and typically occur in $D P W$ of $P K S$ of West Java.

- The author conducted an inventory of communication components that were done repeatedly. In political communication conducted by $P K S$ to carry the openness of ideology of his party.

- After doing an inventory, then the author made a model of communication conducted by $D P W$ of $P K S$ of West Java.

\section{RESULTS AND DISCUSSION}

\section{A. Political Communication Activities in the Openness of Ideology of DPWof PKS of West Java}

There are three discrete units of communication activity i.e. situations, events and acts of communication. The communication activity that the author intends is an activity that takes place in every political communication process related to the openness of ideology of $D P W$ of $P K S$ of West Java through Regional Deliberation, Regional Work Meeting and Regional Coordination Meeting. Regional Deliberation, Regional Work Meeting and Regional Coordination Meeting is an activity in which there is interaction and delivery of messages from communicators to communicant [9].

Political communication conducted by $D P W$ of $P K S$ of West Java cannot be separated from party activities, where activities carried out within the scope of political organizations that are certainly related to communication within an organization. Organizational communication occurs in a complex open system, influenced by its own environment both internal and external, including messages, goals, directions and media [10].

Political communication activities in the openness of ideology of $D P W$ of $P K S$ of West Java took place in the room within the hotel and in open space (field), such as Regional Consultation, Regional Work Meeting and Regional Coordination Meeting. The language used in every communication is Indonesian, both in the form of speech and direction in verbal or nonverbal such as political behaviour or action with the aim of ideological openness will be understood by the audience.

Communication can only live in social interaction, because communication requires the transfer of meaningful symbols. Thus, communication will not happen in a communicative without the language as a symbol and the creation of the message related to the openness of ideology of $D P W$ of $P K S$ of West Java, both in verbal and nonverbal language. The verbal and nonverbal language used in communicating ideological openness is the most important thing to interact in political communication. Therefore every political party has its own political communication pattern to communicate the message or political action units [8].

1) Communicative situation related to political communication in the openness of ideology of DPW of PKS of West Java

The communicative situation is the context of communication, as explained by Ibrahim, that the situation may be the same even if its location changes as in a train, bus or car, or may change in the same location when different activities take place at a different time [11]

Based on that, the communicative situation related to political communication in the openness of ideology of $D P W$ of $P K S$ of West Java is the situation at the location or place of the communication process takes place. The communicative situation is the situation that occurs in the Regional 
Deliberation, Regional Work Meeting and Regional Coordination Meeting in the political communication between $D P W$ of $P K S$ of West Java and internal and external communicant that occurred at different locations, such as in the room in the hotel or outdoors (open field).

Communicative situation related to political communication in the openness of ideology of $D P W$ of $P K S$ of West Java occurs formally and informally conducted by communicators and internal and external communicant. Communication tends to use one-way communication, whereas two-way communication only occurs in small scale.

2) Communicative events related to political communication in the openness of ideology of DPW of PKS of West Java

In addition to communicative situation, it is important to review communication patterns in each analysis of communication. Communication components in ethnography of communication is very important because through communication component the communication event can be identified [8].

It can be said that communicative event is the basic unit for descriptive purpose, which also identifies communicative behavior in every communication activity, because there is an interaction in the political communication activities implemented by $D P W$ of $P K S$ of West Java [11]. Any interaction in political communication will indicate the behaviors, and at the time of the communication process took place, all language forms can be identified both verbal and nonverbal through the delivery of speech and direction.

3) Communicative acts related to political communication in the openness of ideology of DPW of PKS of West Java

Communicative act is a process of communication, and the communicative act is the unit of analysis of the last communication activity and most decisive in every communication event. Communicative acts are generally coterminous with a single interaction function such as referential, request or order and may be verbal or nonverbal [9]. Silence can be a conventional communicative act, such as to ask, promise, refuse, warn, insult, beg or rule.

Therefore, communicative acts on political communication of the openness of ideology of DPW of PKS of West Java are found in the Regional Deliberations, Regional Work Meetings and Regional Coordination Meetings which consist of orders, statements, expectations, requests and advice.

B. Political Communication Components in Communication Ethnography related to the Openness of ideology of Regional Leadership Council (DPW) of PKS of West Java

Communication events can be identified by communication components [8]. Based on the communication events, each component is presented in accordance with political communication activities in the openness of ideology of $D P W$ of $P K S$ of West Java, as follow:

\section{1) Objectives or functions}

Generally, the objectives and functions of political communication in the openness of ideology of $D P W$ of $P K S$ of West Java are to provide information, to build party image, as well as internal and external consolidation to achieve political goals such as party image, good cooperation with all elements of the nation, political participation and political recruitment.

\section{2) Setting/scene}

Place of communication was in the room of the hotel, and outdoors (open field). While the situation related to psychological concerning the atmosphere of formal, informal, relaxed, and so on.

\section{3) Participants}

Both internal and external communicators and internal and external communicants.

4) Message forms

Message form is in the form of verbal (spoken) or nonverbal (sign) language. Language used in the political communication was Indonesian (formal) and Sundanese (informal) through speeches and directives as well as political actions / behaviour that show the openness of ideology.

\section{5) Message content}

Message content was related to the openness of ideology proposed by $P K S$ in the form of speeches or directives and others.

\section{6) Act sequence}

Act sequence in the political communication related to the openness of ideology was through verbal message or actions/behaviours (nonverbal). So that the sequence of communication acts is communication steps that continuously cannot be broken before or after communication event about the openness of ideology of $D P W$ of $P K S$ of West Java.

7) Interaction rules

The rules found in political communication related to the openness of ideology of $D P W$ of $P K S$ of West Java were Regional Deliberation held at least 1 (once) in a period of leadership that is 5 (five) years while the Regional Work Meeting and Regional Coordination Meeting, at least held 2 (twice) in a period of leadership.

\section{8) Norms of interpretation}

The norms related to political communication in the openness of the ideology of $D P W$ of $P K S$ of West Java is a rule that is used as a reference to stand as a political party.

C. The Relationship between Communication Components in Communicative Events that Form the Communication Pattern Related the Openness of Ideology of DPW of PKS of West Java

The communication pattern in the political communication in the openness of ideology of $D P W$ of $P K S$ of West Java is a formal communication pattern, through organizational 
channels through Regional Deliberation, Regional Work Meeting and Regional Coordination Meeting with vertical communication between leaders and followers, horizontal among fellow administrators, cadres / members, internal and external communications, and one-way, two-way or circular communication. It is used to communicate ideological openness, such as inclusive, moderate, cooperative, tolerant, accepting plurality, to eliminate negative stigma, internal and external consolidation. Political communication is very important considering $P K S$ is a political party whose purpose is to get support, power, and position.

The following is the communication pattern in political communication in the openness of ideology of $D P W$ of $P K S$ of West Java, both verbal and nonverbal.

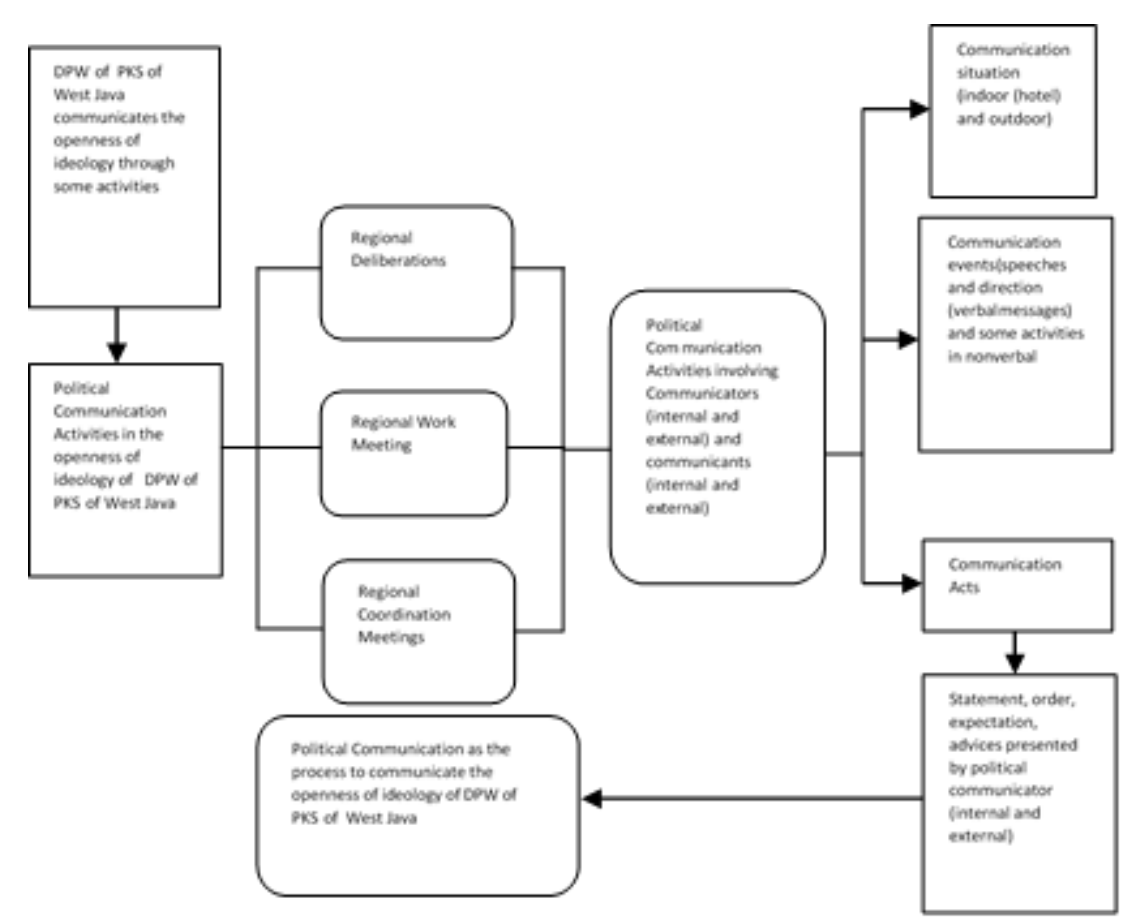

Fig. 1. Communication pattern in Political Communication in the openness of ideology of DPW of PKS of West Java.

\section{CONCLUSION}

Political communication activities in the openness of ideology of $D P W$ of $P K S$ of West Java can be seen in its whole political communication activities done such as Regional Deliberations, Regional Work Meetings and Regional Coordination Meetings. Political communication activities can be understood as a form of internal and external consolidation, good cooperation with all elements of the nation, the image of an inclusive party, the loss of stereotype of Ihwanul Muslimin or Wahhabism, moderate, and accepting plurality. Communication activities are conducted formally and informally (officially and casually), both indoor (hotel) and outdoor (open field). Therefore, communication patterns in the political communication in the openness of ideology in the organization are generally same in every activity undertaken.

\section{REFERENCES}

[1] A. Arifin, Komunikasi Politik Filsafat-Paradigma-Teori-Tujuan-Strategi dan Komunikasi Politik Indonesia. Yogyakarta: Graha Ilmu, 2011.

[2] D. Nimmo, Komunikasi Politik Komunikator, Pesan, dan Media. Bandung: PT. Remaja Rosdakarya, 2008.

[3] M. M. Hikmat, Komunikasi Politik Teori dan Praktik. Bandung: Simbiosa Rekatama Media, 2001.

[4] R. Al-Hamdi, Partai Politik Islam Teori dan Paraktik di Indonesia. Yogyakarta: Graha Ilmu, 2013.

[5] A. Taufik Hirzi, Menyimak Gerakan Dakwah Politik PKS Ekspansi Gerakan Tarbiyah PKS Kota Bandung. UNPAD Press, 2009.

[6] H. Cangara, Komunikasi Politik Konsep, Teori, dan Strategi. Jakarta: Rajawali Pers, 2014.

[7] J. Creswell, Qualitative Inquiry and Research Design : Choosing among Five Traditions. USA : Sage Publications, 1998.

[8] E. Kuswarno, Etnografi Komunikasi. Bandung: Widya Padjadjaran, 2008.

[9] I. A. Syukur. Panduan Penelitian Etnografi Komunikasi. Surabaya: Usaha Nasionalan, 1994.

[10] A. Muhammad, Komunikasi Organisasi. Jakarta: PT. Bumi Aksara, 2008. 
[11] S. Harmin, Komunikasi Budaya Suku Bajo Dalam Pemenuhan Gizi Balita (Studi Etnografi Komunikasi Tentang Komunikasi Suku Bajo
Dalam Pemenuhan Gizi Balita Di Kabupaten Konawe Sulawesi Tenggara)(disertasi). Bandung, Universitas Padjadjaran, 2011. 